\title{
AUGUST STRINDBERG, GOLDMAKER
}

\author{
George B. Kauffman
}

Department of Chemistry, California State University, Fresno, CA 93740, USA

\begin{abstract}
Strindberg, the 'Shakespeare of the North', was obsessed with a passion for producing gold, and, like many alchemists before him, he failed to temper his imagination with reality. But his goldmaking 'research', like his other scientific studies, provides a valuable case study of a humanist genius whose amateur scientific activities enriched his literary and dramatic productions.
\end{abstract}

August Strindberg (1849-1912), Sweden's greatest writer and a follower of Haeckel and Darwin, believed in transmutation and sought a single origin for all matter, inanimate as well as animate [1-5]. Although, with a few exceptions [7-10], his scientific studies have been neglected compared to his dramatic and literary productions, several recent articles [11-16] seem to indicate an increasing interest by historians of science in this fascinating aspect of the work and thought of the 'Shakespeare of the North'. Strindberg's attempts to synthesize gold illustrate the differences between the experimental approach of a gifted amateur who happened to be a genius in his own field and that of a professional scientist. This article briefly considers one phase of his al-

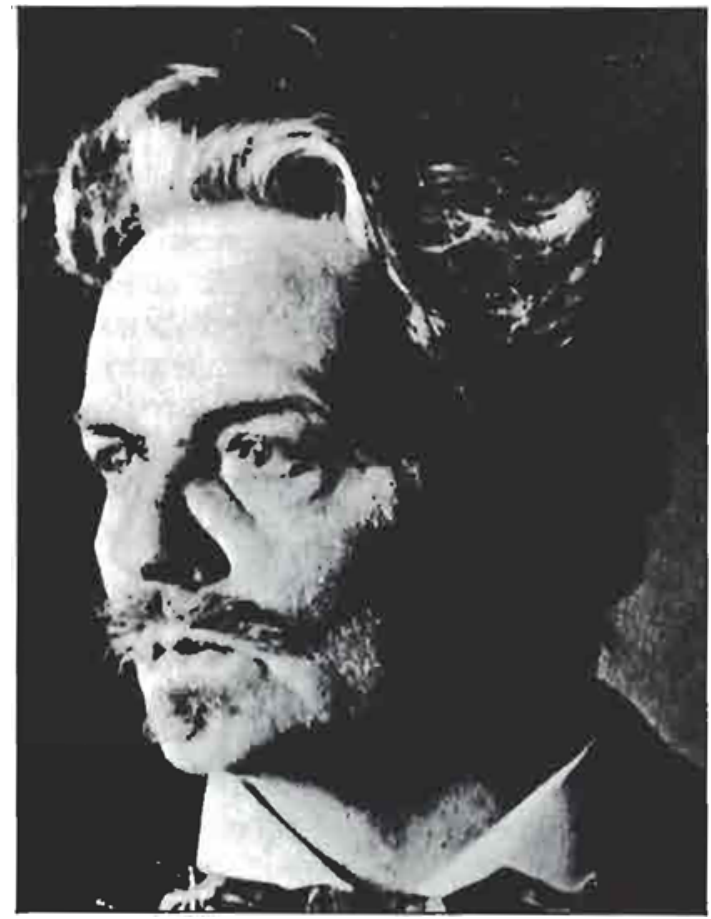

Fig. 1 August Strindberg chemical research - his attempts to synthesize gold from other elements - in terms of modern chemistry. It also will present the results of nondestructive analyses of eight of his 'gold samples'.

\section{Strindberg's Characteristics as a Scientist}

As a scientist, Strindberg was largely self-taught. In 1869 he failed his preliminary examination in chemistry at Uppsala University and left Uppsala in a rage, con- vinced that the examiners had a personal grudge against him. Thus his subsequent chemical research may have been consciously or subconsciously motivated by his need to vindicate himself in the eyes of 'establishment' scientists. Most of his experiments were crude, non-quantitative, and lacking in objectivity and proper scientific controls. His "uncontrolled subjectivity and inordinate need of selfpersonification", to use Martin Lamm's apt words, were traits of immense value to him as a playwright and novelist, but they militated against his success as a scientist. He worked impulsively and obsessively with a selective approach that seized upon 'evidence' apparently favoring his idée fixe of transmutation and the unity of matter, yet he disregarded whatever observations did not support his hypothesis.

One of the primary requirements for a successful scientist is the ability to discriminate between significant observations and those which are merely random or coincidental. Strindberg, with his superstitious and paranoid personality, regarded all sorts of fortuitous events and experimental observations as pregnant with meaning or evidence of the action of makterna (the Powers) [17], which he believed had singled him out for special reward 


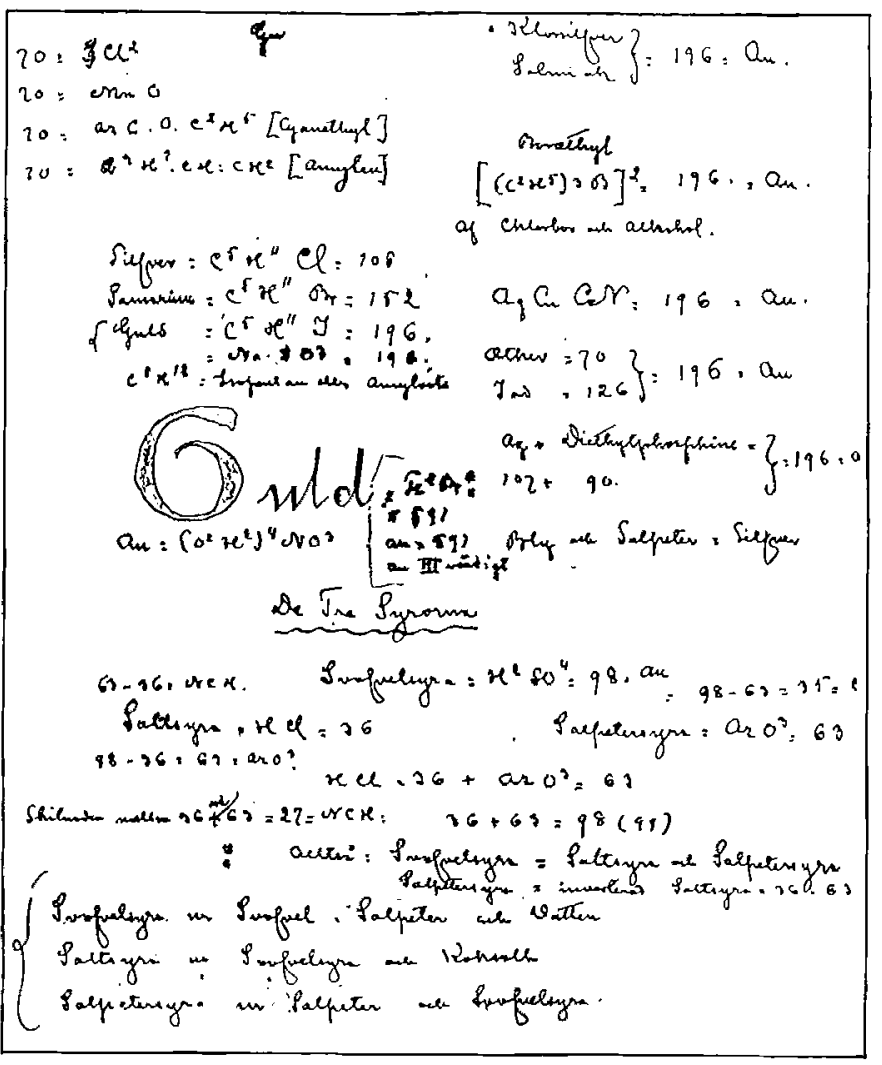

Fig. 2 A page from Strindberg's holograph papers [24]

or torment, depending upon his mood at the time. Two examples closely related to his work on gold illustrate his reliance on coincidence, which underlies many of his scientific theories and conclusions as well as many of the decisions that he made during his life.

First, in a letter of 7 July, 1896 to his friend Torsten Hedlund, Strindberg related how one morning he had found a copy of an obsolete book on chemistry [18] by the Minorca-born forensic chemist Matthieu-JosephBonaventure Orfila (1787-1853) [19] in an antiquarian bookshop on the Boulevard St. Michel in Paris. He wrote to Hedlund that shortly thereafter, when he saw a monument to Orfila in the churchyard of Montparnasse and encountered the Hôtel Orfila (60 rue d'Assas), a 'pension' for monks and students, he moved and lived there from 21 February, 1896 to 19 July, 1896. Strindberg declared, "It was there that I solved the gold problem" with the aid of Orfila's book, which confirmed some of his own views of the elements [20].

Second, in his autobiographical novel Inferno [21] Strindberg describes an alley wall in the Parisian suburb of Meudon:

I noticed a charcoal inscription on the whitewash.

Seeing the letters $F$ and $S$ intertwined made me think of my wife's [22] initials. She still loved me! - The next instant I was illumined by a vision of the chemical signs for iron ( $\mathrm{Fe}$ ) and sulfur (S), and displaying the secret of gold before my eyes .... I returned to Paris convinced that I had witnessed something like a miracle [23].

After this fortuitous, commonplace event, various combinations of iron and sulfur (e.g., $\mathrm{Fe}_{3} \mathrm{~S}$, which Strindberg thought had a molecular weight of 196 and therefore was identical with gold) figure prominently in Strindberg's 'syntheses of gold'.

In common with the Pythagoreans of antiquity, Strindberg was fascinated, one might even say, obsessed, with numbers. Page after page of his holograph chemical papers [24], are filled with calculations involving innumerable combinations of various unrelated substances whose atomic weights or molecular weights just happen by sheer coincidence to add up to atomic weights or molecular weights of desired substances $(196,197$ or 392 in the case of gold) (Figure 2). If this were the case, he considered the substances to be related or even identical. Such arbitrary calculations, which formed the basis of his experiments, are more akin to numerology than to the scientific efforts of a true quantitative scientific systematizer such as Mendeleev.

Like the alchemists of old, Strindberg had a mystical belief in analogies, correspondences, and superficial resemblances. In his eyes, if a substance looked like gold, it was gold. If, unlike true gold, it was found to be soluble in nitric acid, he considered it to be unfixed or incomplete gold [25]

Science makes frequent use of Ockham's razor (Non sunt multiplicanda entia praeter necessitatem; Entities are not to be multiplied beyond necessity), by choosing the simplest hypothesis in preference to more complex ones. Yet Strindberg often violated this principle of formal logic in favor of more exotic or fanciful explanations. For example, in attributing a mundane occurrence involving a pair of pants to the influence of makterna, Strindberg admonished his friend Albert Engström,

You are impossible. You are only a realist and there-

fore nothing ever happens to you [26].

It is true that Einstein stated that "imagination is more important than knowledge". Yet, unlike a competent professional scientist, Strindberg failed to temper his imagination with reality. In The Svedberg's words,

Strindberg was no scientist. In his innermost nature he was a stranger to all real research [27]. 


\section{Strindberg's Interest in Gold}

Like many alchemists before him, Strindberg was obsessed with a passion for producing gold that went beyond a consideration of its unique physical and chemical properties. In his holograph papers [28] is a quotation from Scene 1 of Richard Wagner's Das Rheingold describing the power of a ring forged from the gold guarded by the Rhinemaidens, showing that Strindberg was well aware of the mystique associated with the king of metals since antiquity:

Nur wer der Minne Macht entsagt,
Nur wer der Liebe Lust verjagt,
Nur der erzielt sich den Zauber,
Zum Reif zu zwingen das Gold.
(Woglinde)
... So verfluch' ich die Liebe!

(Alberich) [29]

Franklin S. Klaf, an American psychiatrist, thought that Strindberg's alchemical experiments provided an outlet for the paranoid hostility typical of schizophrenics [30]. In Till Damaskus (To Damascus) [31], the first of his dream plays, Strindberg revealed that gold-making fed his megalomaniacal feelings of grandiosity. He would be

a man who has done what no one else has ever done; who will overthrow the Golden Calf and upset the tables of the money changers. I will hold the fate of the world in my crucible.

He proclaimed that transmutation of base metals into gold was intended not for accumulating wealth but as a calculated destructive act:

I'll do it to paralyze the present order, to disrupt it as you'll see. I am the destroyer, the dissolver, the world incendiary; and when all lies in ashes, I shall wander hungrily through the heaps of ruins, rejoicing at the thought that it is all my work: that I have written the last page of world history, which can then be held to be ended.

As a follower of Haeckel and Darwin, Strindberg believed that the number of elements was much fewer than generally believed and that many substances commonly thought to be elements were complex aggregates formed from simpler elements (e.g., hydrogen, carbon and oxygen) by a process similar to evolution among plants and animals. This belief in a single origin for all matter, which was within the realm of normative nineteenth-century chemistry and which coincidentally adumbrates our modern views of the constitution of matter as being composed of subatomic particles (protons, neutrons and electrons), underlay his belief in transmutation. Gold, considered the most perfect of metals, was therefore potentially obtainable from less noble, base metals.

\section{Strindberg's Works on Gold-making}

Concern with gold appears not only in many of Strindberg's scientific studies but also in some of his literary and dramatic works. Among his general scientific works, those which deal with gold include Antibarbarus (1894) [32], Introduction à une Chimie Unitaire (1895) [33], Typer och Prototyper inom Mineralkemien (1898) [34] and En Blå Bok (1907-1908) [35].

Gold is also frequently mentioned in his correspondence (1894-1902) with the Parisian alchemist François Jollivet Castelot (Bréviaire Alchimique, 1912) [36], in his Ockulta Dagboken (The Occult Diary) (1896-1908) [37], and in many of his letters [38]. But his most detailed directions for gold-making are found in a short article, Synthèse d'Or (Synthesis of Gold), in the Parisian journal L'Hyperchimie [39], in Guldets syntes (Synthesis of Gold) (1896) [40], Nutidens guldmakeri (Today's Gold-Making) (1896) [41], the article Les Gîtes Aurifères de la France (The Gold-Bearing Strata of France) [42] and the document Livre d'Or (Book of Gold) [43].

In Berlin during March 1894, together with his friend, the surgeon Carl Ludwig Schleich, Strindberg submitted to the chemist Hans Heinrich Landolt (1831-1910) and the pharmacologist Oscar Liebreich (1839-1908) some paper sheets speckled with 'gold', which he claimed to have made by transmutation, but the two University of Berlin professors were unimpressed [44]. This was only one of numerous occasions on which Strindberg showed or gave 'gold samples' to friends or relatives. His third wife, the Norwegian actress Harriet Bosse (1878-1961), to whom he confided his methods for producing 'gold', reported that "he took a much greater pride in his scientific discoveries than he did in being a great author" [45]. A number of Strindberg's 'gold samples' are preserved among Strindberg's papers at the library of Lunds Universitet (University of Lund) and Kungliga Biblioteket (The Royal Library), Stockholm.

\section{Strindberg's Synthèse d'Or}

Three relatively simple 'gold syntheses' by Strindberg appear in L'Hyperchimie [46] and are typical of his work and thought on this subject (Figure 3). They also appear in a number of his other published works. In my translation, which follows, my annotations and corrections to Strindberg's work appear in square parentheses: 


\section{Synthesis of Gold}

Ammoniacal iron sulfate $=\mathrm{Fe}\left(\mathrm{Az}, \mathrm{H}^{4}\right)^{2}\left(\mathrm{SO}^{4}\right)^{2} 6 \mathrm{aq}=392$.

The molecule of gold $=\mathrm{Au}^{2}=392$.

Perhaps the solution of the enigma:

\section{Starting Point}

Iron sulfate (green copperas) $\left[\mathrm{FeSO}_{4} \cdot 7 \mathrm{H}_{2} \mathrm{O}\right]$ precipitates solutions of gold. According to monistic chemistry, to precipitate means to enter as a factor in the reconstitution of a decomposed substance.

\section{Fundamental Experiment}

A strip of paper is soaked in a solution of iron sulfate [and] held over the fumes from a bottle of ammonia. This paper is colored blue-green like gold protoxide [ $\left.\mathrm{Au}_{2} \mathrm{O}\right]$. It is dried above a lighted cigar, and the paper is colored maroon like gold deutoxide $\left[\mathrm{Au}_{2} \mathrm{O}_{3}\right]$. But gradually shining yellow scales of metallic gold are formed constituting an unfixed gold, when the iron sulfate produces a self-fertilization by being precipitated itself.

However, the shining yellow scales amalgamate with mercury. Therefore it is at least no longer iron, since iron does not amalgamate with mercury.

Nevertheless, the strips of paper are colored blue by yellow fer-

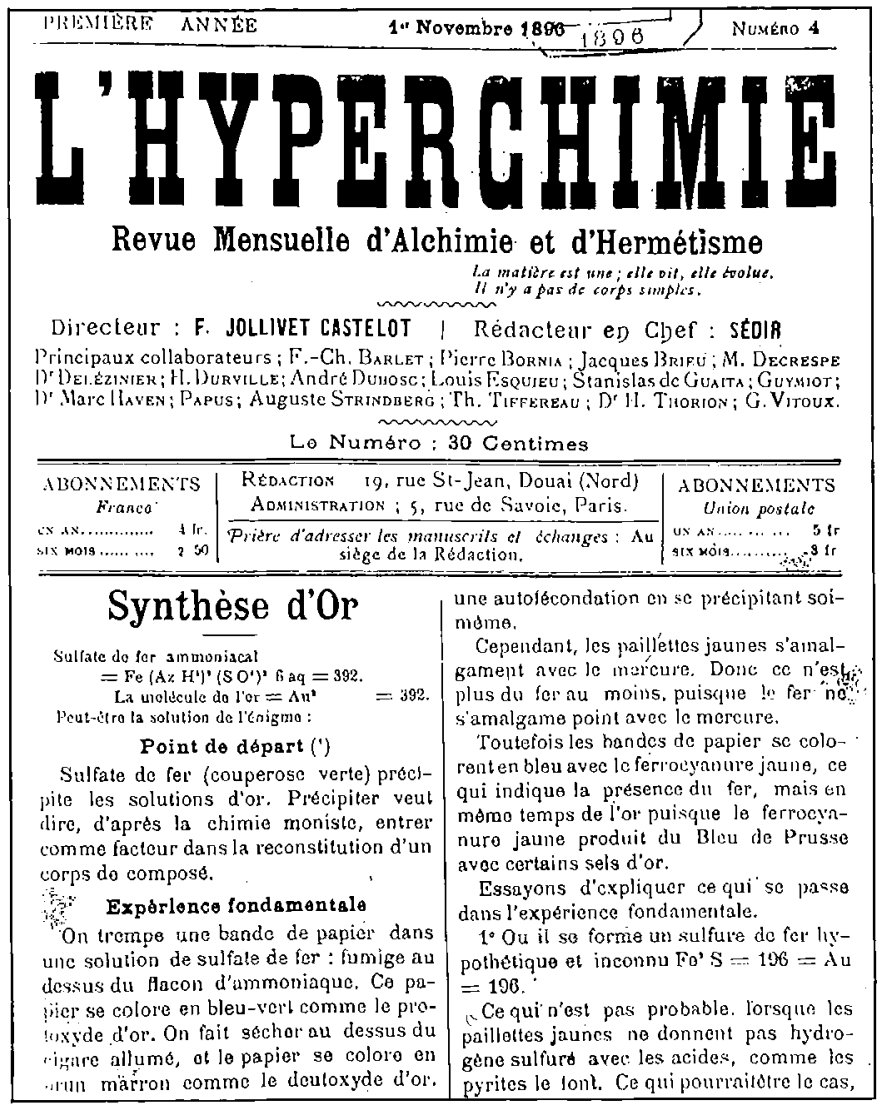

Fig. 3 One of Strindberg's articles on the synthesis of gold was published in $\mathbf{1 8 9 6}$ in L'Hyperchimie - a monthly review of alchemy and hermetism rocyanide $\left[\mathrm{K}_{4}\left[\mathrm{Fe}(\mathrm{CN})_{6}\right]\right]$, which indicates the presence of iron, but at the same time of gold since yellow ferrocyanide produces Prussian blue $\left[\mathrm{KFe}\left[\mathrm{Fe}(\mathrm{CN})_{6}\right]\right]$ with certain salts of gold.

Let us try to explain what happens in the fundamental experiment.

1). Either there is formed a hypothetical and unknown iron sulfide, $\mathrm{Fe}^{3} \mathrm{~S}=196=\mathrm{Au}=196$ [actually 199.58].

Which is not probable when the yellow shining scales do not give hydrogen sulfide with acids as pyrites do. Which could be the case since gold accompanies pyrites.

2). Or there is formed an unknown hydrated iron oxide, $\mathrm{Fe}^{2} \mathrm{O}^{3}+2 \mathrm{H}^{2} \mathrm{O}=196=\mathrm{Au}=196$.

Which could be likely when auriferous gravel are always ferruginous

3). Or there is formed an ammoniacal iron sulfate: $\mathrm{Fe}\left(\mathrm{AZH}^{4}\right)^{2}\left(\mathrm{SO}^{4}\right)^{2} 6 \mathrm{H}^{2} \mathrm{O}=392$. The number 392 indicates exactly the molecular weight of gold chloride $=392$, which allows one to think, and gold chloride is reduced by the nicotine [of the cigar] reducing agent of gold salts.

What renders this last reaction probable? A fact drawn from the old chemistry.

Orfila has said: Ammoniacal iron trisulfate is produced by dissolving gold [?] in ammonium chloride and nitric acid and by precipitating it by iron sulfate.

To make use of a solution of gold in order to produce a simple compound of iron indicates an intimate relation between the constitution of gold and of iron.

Finally, this unfixed and incomplete gold dissolves in nitric acid alone and in hydrochloric acid, a property, however, in common with extremely attenuated gold.

\section{Experiment II}

The self-fertilization of iron has given a bad offspring, and it is necessary to cross this metal with another which possesses the more accentuated properties of gold.

Copper, belonging to the second group of metals, different from the first or that of iron by several qualities, already appears by nature to be designated as the female when chalcopyrites, combined sulfides of iron and copper, produce a more perfect gold than the simple sulfides of iron.

A strip of paper is soaked in cuprous chloride $\mathrm{Cu}^{2} \mathrm{Cl}^{2}[\mathrm{CuCl}]$, then soaked in iron sulfate and held over the fumes of ammonia and a cigar. This gold is more resistant and more lustrous.

The reaction could be explained as follows:

$\mathrm{Cu}^{2} \mathrm{Cl}^{2}=196=\mathrm{Au}=196$.

How is this cuprous chloride produced? By precipitating copper sulfate with tin chloride $\left[\mathrm{SnCl}_{2}\right]$.

But tin chloride precipitates gold from its solutions. Thus copper sulfate appears to be endowed with the possibility of forming a gold.

This synthesis of gold is confirmed and verified for the procedure named after Falun, applied to the extraction of gold from chalcopyrites or combined sulfides of iron and copper. Two copper mines exist in Sweden where gold has always been extracted: Falun and Adelfors.

This is the procedure in the simplest form, corresponding exactly to the synthesis presented below. 
Chalcopyrites are roasted with sodium chloride; iron chloride is

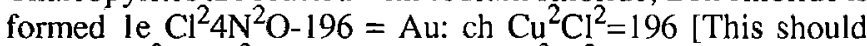
read ' $\mathrm{FeCl}{ }^{2}+4 \mathrm{H}^{2} \mathrm{O}=196=\mathrm{Au}$ and $\mathrm{Cu}^{2} \mathrm{Cl}^{2}=196$ '. Actually, the correct values are 198 and 198.75 , respectively].

The ores are treated with calcium chloride and sulfuric (or hydrochloric) acid, whereby they become chlorinated. Then as a final step they are precipitated by iron sulfate. This is all, and it is exactly the operation mentioned here.

\section{Experiment III}

\section{Simplified method for a large yield}

In a bucket I pour 1 copper sulfate, 3 iron sulfate, 1 ammonium chloride, and ammonia at will. Then I fill the bucket with water and allow it to stand in the sun or in front of a fire.

On the surface of the water heavy specks appear after a few hours, or better, after a day of waiting. The heavy specks are recovered on paper and allowed to dry at leisure. On adding ammonia, the production continues for weeks.

\section{Auguste Strindberg}

Saxen near Grein, Upper Austria, 15 September 1896

Strindberg asked John Landin, an engineer, to analyze his 'gold samples'. Landin found them to consist of a mixture of iron(III) hydroxides and oxides as might be expected from Strindberg's procedures.

He published his analytical results [47], and Strindberg reacted angrily and publicly declared Landin's results to be erroneous [14, 48, 49].

Space limitations prevent my considering Strindberg's gold-making activities in more detail. For this the reader is referred elsewhere [50-55].

\section{Modern Interpretations and Analyses}

In attempts to reproduce Strindberg's results, I followed his directions, which was somewhat difficult since he gave few details and little in the way of quantities. In the 'Fundamental Experiment' the blue-green spot was undoubtedly unstable iron(II) hydroxide, which, on drying over a cigar, oxidized to form a brownish orange spot of iron(III) hydroxide, which could be construed as gold only by someone as imaginative and already convinced of the possibility of transmutation as Strindberg.

My results for 'Experiment II' were essentially the same. Copper(I) chloride is insoluble and probably had no effect on the reaction; any that did dissolve probably oxidized to copper(II) chloride.

My results for 'Experiment III' $\left(3 \mathrm{~g} \mathrm{NH}_{4} \mathrm{Cl}, 3 \mathrm{~g}\right.$ $\mathrm{CuSO}_{4} .5 \mathrm{H}_{2} \mathrm{O}$ and $9 \mathrm{~g} \mathrm{FeSO}_{4} .7 \mathrm{H}_{2} \mathrm{O}$ dissolved in $600 \mathrm{ml}$ of $\mathrm{H}_{2} \mathrm{O}$ followed by addition of $5 \mathrm{ml}$ of concentrated aqueous $\mathrm{NH}_{3}$ ) were more successful. First, a shimmering film of orange-brown flakes resembling gold appeared on the sur-

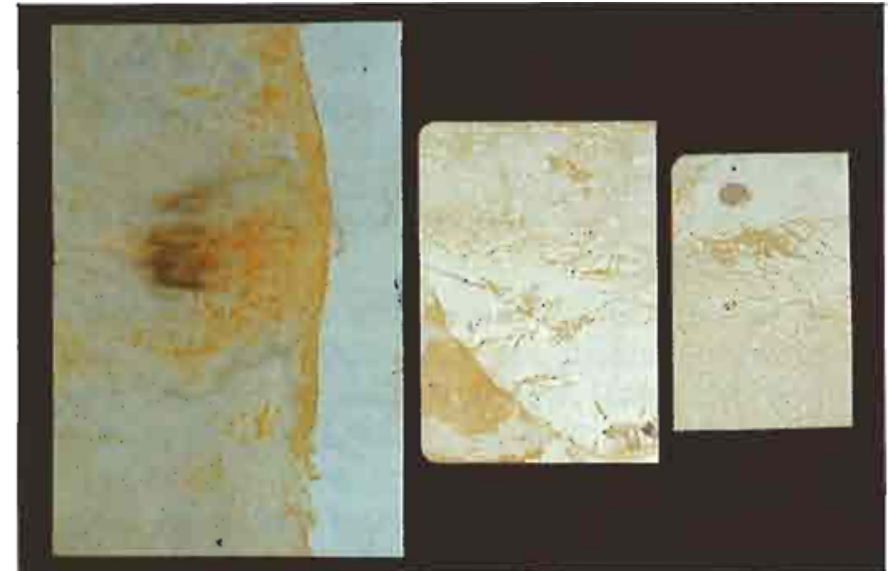

Fig. 4 Some of Strindber's 'gold samples' on paper preserved at the Kungliga Biblioteket in Stockholm

face of the liquid. This eventually settled to the bottom of the beaker as a muddy brown precipitate. The supernatant solution was colored deep purple by the stable tetraamminecopper(II) ion ( $\left.\mathrm{Cu}\left(\mathrm{NH}_{3}\right)_{4}{ }^{2+}\right)$.

Through the kindness of Prof. Levi Tansjö, Chairman of the Organic Chemistry Department, Lunds Universitet, and Margareta Brundin, Handskriftavdelningen, Kungliga Biblioteket, I was able to obtain analyses of some of Strindberg's 'gold samples' (impregnated paper) preserved at the two institutions. The samples looked much more like gold than those that I had prepared. The color reproduction (Figure 4) does not look nearly as much like gold as the actual samples.

Seven samples from Kungliga Biblioteket (4 from Sg NM 29, 2 from Sg NM 31 and 1 from Sg NM 37) were selected by Dr. Brundin, together with Prof. Lennart Bäckerud, Institute for Structural Chemistry, The Arrhenius Laboratory, Stockholms Universitet, under whose direction the analyses were carried out by his graduate student Mr. Rein Kiusalaas. The samples were analyzed qualitatively for metallic elements (atomic numbers $>11$ ) in an X-ray fluorescence spectrometer using an end-window $\mathrm{Rh}$ anode tube for excitation of characteristic X-ray spectra. No gold was found in any of the samples except for one in which gold was used as a starting material. All the samples, however, contained iron in reasonable amounts or as a major component.

A 'gold sample' from Lunds Universitet Biblioteket was analyzed by Drs. Börje Folkesson and Ragnar Larsson of the Department of Inorganic Chemistry, Chemical Center, Lunds Universitet by ESCA (electronic spectra for chemical analysis), a technique capable of detecting as little as $100 \mu \mathrm{g}$ of gold or as little as $0.58 \mu \mathrm{g}$ of gold on the surface of the paper. They found that the sample contained 
large amounts of iron and oxygen showing that the yellow material on the paper was probably iron(III) oxide, in agreement with John Landin's results obtained eightyeight years earlier.

\section{Conclusions}

As we have seen, the scientific value of Strindberg's work on gold-making per se, like that of his other chemical and alchemical studies, is minimal. His undue emotional involvement and his mystical belief in analogies, correspondences and numbers resulted in an almost complete lack of objectivity in his experiments and theories. Svedberg concluded,

The value of Strindberg's chemical writings is wholly of a literary and psychological nature. Especially in the future they should be of extraordinary significance in judging his spiritual development .... also his scientific studies have undoubtedly fertilized his writing to a high degree, enriched it with new and fresh images, and in an unusual way have brought him into intimate contact with the world surrounding him [56].

In Evert Sprinchorn's words, "As a scientist, Strindberg was a superb poet" [57], while Gunnar Brandell stated, "In my book [Strindbergs Infernokris [58]] I chose to regard Strindberg's chemical speculations as a kind of poetry rather than science" [59]. Yet, despite their shortcomings, Strindberg's chemical and alchemical work found expression in his writing. Thus Strindberg's goldmaking 'research', like his other scientific studies, provides a valuable case study of a humanist genius whose amateur scientific activities enriched his literary and dramatic productions.

\section{Acknowledgments}

I wish to acknowledge the U.S. National Endowment for the Humanities (Grant No. RO-20301-82) for financial assistance and Svenska Institutet for a Strindberg Fellowship, which provided accommodation at Blå tornet, Strindberg's last residence in Stockholm, while I worked at Strindbergsmuseet and Kungliga Biblioteket. I am indebted to the California State University, Fresno for an institutional research grant and a sabbatical leave of absence. I also wish to thank Stellan Ahlström, Gunnar Brandell, Margareta Brundin, Thérèse Kleindienst, Lennart Kullberg, Mary McIntyre, Robert Michelotti, Gunilla Norming, Anita Persson, Carl Reinhold Smedmark, Evert Sprinchorn and Levi Tansjö.

\section{References}

I V.J. McGill, August Strindberg: The Bedeviled Viking, Brentano's, New York, 1930; Russell \& Russell, New York, 1965

2 B.M.E. Mortensen and B.W. Downs, Strindberg: An Introduction to His Life and Work, Cambridge University Press, Cambridge, England, 1949

3 E. Sprigge, The Strange Life of August Strindberg, Russell \& Russell, New York, 1949, 1972

4 M. Lamm, August Strindberg, (ed. \& transl. H.G. Carlson), B. Blom, New York, 1971

5 G. Brandell, Strindberg in Inferno, (transl. B. Jacobs), Harvard University Press, Cambridge, Mass., 1974

6 O. Lagercrantz, August Strindberg, Wahlström \& Widstrand, Stockholm, 1979

7 B. Lidforss, 'Strindberg som naturforskare', Nordisk Revy, 1895, 1, 157-161

8 L. Benda, 'August Strindberg als Naturforscher', Die Umschau, 1908, 12, 498-501

9 G. Schmid, 'Strindbergs naturwissenschaftliche Schriften', Deutsche Rundschau, 1917-18, 44, 70-97

10 The Svedberg, (a) 'Strindberg som kemist', Forum, 1918, 5, 3-31; reprinted in (b) Forskning och industri: Naturvetenskapliga essayer, H. Gebers Förlag, Stockholm, 1918, pp. 76-100

11 B. Jönsson, 'Strindberg: kemist och guldmakare som The Svedberg såg honom', Kemisk Tidskrift, 1980, 42(5), 6-8

12 G.B. Kauffman, 'August Strindberg's Chemical and Alchemical Studies', J. Chem. Ed., 1983, 60, 584-590

13 G. Tengvall, 'Kemiprofessor skriver om Strindberg: Han var en ovetenskaplig alkemist med stor fantasi', Dagens Nyheter, July 1, 1983, 16

14 Ch.-V. Grewe, 'August Strindberg und die Chemie', Sudhoffs Archiv, 1984, 68(1), 2 l-42

15 E. Vaupel, 'August Strindberg als Naturwissenschaftler', Chemie in unserer Zeit, 1984, 18(5), 156-167

16 G.B. Kauffman, 'Strindbergs kemiska spekulationer poesi snarare än vetenskap', Kemisk Tidskrift, 1985, 97(11), $51-55,57$

17 M. Lamm, Strindberg och makterna, Svenska kyrkans diakonistyrelses bokförlag, Stockholm, 1936

$18 \mathrm{M}$. Orfila, Elements de Chimie appliqués à la Médecine et aux Arts, 5 th ed., 2 vols., Lib. de Crochard, Paris, 1831

19 Enciclopedia Italiana di Scienze, Lettere ed Arti, Istituto della Enciclopedia Italiana, Rome, 1949, 25, 507

20 A. Strindberg, "August Strindbergs brev utgivna av Torsten Hedlund', A. Bonniers Förlag, Stockholm, $1969,11,245-246$

21 Strindberg's stay in Paris (August 1894 - Summer 1896) has become known as his Inferno Period or his Inferno Crisis (ref. 3 , chap. 12 ; ref. 4 , chap. 14; ref. 5), since it eventually culminated in his novel Inferno, written in Lund ( 3 May - 25 June, 1897) describing his conversion from a materialistic atheism to his own eclectic and mystical religion based on the tenets of the Swedish scientist, mystic and philosopher, Emmanuel Swedenborg (1688- 
1722) and others. In Paris Strindberg turned his back on the literary world, abandoned his creative writing and obsessively pursued both theoretical and laboratory studies of the natural sciences (chemistry, botany and optics) and occult sciences (alchemy, theosophy, mesmerism, numerology and cabala) in an effort "to provide the link between science on the one side and occultism and religion on the other'. He regarded his Inferno years, during which he experienced five acute psychotic episodes (ref. 5) as the most intense and exciting of his life, and they had such a profound influence on his artistic development that his literary works are commonly dichotomized as 'pre-lnferno' and 'post-Inferno'.

22 Strindberg's second wife, Frida Uhl (1872-1943) was a 19-year-old Austrian journalist with ambitions of becoming a writer when she met the celebrated 4 I-yearold playwright. Their marriage, which produced one daughter, lasted only a short time (2 May, 1893 - 19 Oct., 1897).

23 A. Strindberg, Inferno, Alone and Other Writings, (transl. E. Sprinchorn), Doubleday \& Co., Garden City, N.Y., 1968, 151

24 Sg NM, Kartonger 27-35, Handskriftavdelningen, Kungliga Biblioteket, Stockholm

25 Grewe, ref. 14

26 A. Engström, August Strindberg och jag, A. Bonnier, Stockholm, 1923, 44-46

27 Svedberg, ref. 10(a), p. 31

28 Sg NM Kartong 30, Handskriftavdelningen, Kungliga Biblioteket, Stockholm

29 He who the sway of love foreswears, He who delight of love forbears, Alone the magic can master That forces the gold to a ring. ... Love henceforth be accursed!

30 F.S. Klaf, Strindberg: The Origin of Psychology in Modern Drama, Citadel Press, New York, 1963, pp. $107,158,169$

31 A. Strindberg, Plays of Confession and Therapy: To Damascus, I, II and III', (transl. W. Johnson) University of Washington Press, Seattle, London, 1979

32 This, Strindberg's first and most important scientific book, was first published in German and later translated into Swedish. A. Strindberg, Antibarbarus I oder die Welt für sich und die Welt fïr mich, Verlag des

Bibliographischen Bureaus, Berlin, 1894; Antibarbarus eller verlden för sig och verlden för mig, Bröderna Lagerström, Stockholm, 1906

33 A. Strindberg, Introduction à une Chimie Unitaire (Première Esquisse), Ed. du Mercure de France, Paris, 1895

34 A. Strindberg, Typer och Prololyper inom mineralkemien, Festskrift till firandet af Berzelii femtioairs minne, C. \& E. Gernandt, Stockholm, 1898

35 A. Strindberg, En blå bok, 3 vol., Björck \& Börjesson, Stockholm, 1907-08; Ein Blaubuch: Die Synthese meines Lebens, (transl. E. Schering), 3 vol., Georg Müller, Munich, 1919-21

36 A. Strindberg, Bréviaire Alchimique: Lettres d'August Strindberg à Jollivet Castelot, Hector et Henri Durville, Paris, 1912

37 A. Strindberg, Ockulta dagboken, Gidlunds Förlag,
Stockholm, 1977

38 Ref. 20,15 vol., 1948 -

39 A. Strindberg, 'Synthèse d'Or', L'Hyperchimie, 1896, 1(4), $1-3$

40 A. Strindberg, 'Guldets syntes förklarad av guldextraktionen ur kopparkis genom faluprocessen', Göteborg Handel-Tidning tryckeri, Göteborg, 1896; reprinted in Samlade Skrifter (Collected Writings), Albert Bonniers Förlag, Stockholm, 1921, 27, 347-350

41 A. Strindberg, Nutidens Guldmakeri, John Björkmans Eftr., Stockholm, 1896; descriptions of syntheses of gold by himself and others addressed to Kemiska Foreningen i Stockholm (Stockholm Chemical Society); reprinted in Samlade Skrifter, Albert Bonniers Förlag, Stockholm, 1921, 27, 336-343. See also C.O. Kjellin, Kemistsamfundels historia, 1883-1933', Kemistsamfundets Förlag, Stockholm, 1933, 59-61

42 A. Strindberg, 'Les Gîtes Aurifères de la France', L'Hyperchimie, 1898, 3(10), 3-5

43 'Livre d'or, det senaste Strindbergsdokumentet', Dagens Nyheter, 10 May, 1914

44 C.L. Schleich, Besonnte Vergangenheit: Lebenserinnerungen (1859-1919), Ernst Rowohlt Verlag, Berlin, 1922,251

45 A. Strindberg, Letters of Strindberg to Harriet Bosse, (ed. \& transl. A. Paulson), Thomas Nelson \& Sons, New York, Edinburgh, Toronto, 1959, 93

46 Ref. 39

47 J. Landin, 'August Strindberg och kemien', Stockholms Dagblad, 13 Oct., 1896. See also J. Landin, 'August Strindberg som guldmakare och radiumforskare: Några alkemistiska Strindbergsbref', Stockholms Dagblad, 17 May, 1914

48 A. Strindberg, 'August Strindbergs guldmakeri' (letter), Dagens Nyheter, 20 Oct., 1896, 3

49 J. Landquist, August Strindberg, Samlade skrifter, Albert Bonniers Förlag, Stockholm, 1921, 27, 707-714

50 'Guldmakeri i nittonde seklet', Norden, 23 Oct., 1896, 24(43), 471-72; 30 Oct., 1896, 24(44), 482-84

51 R. Anderberg, 'När Strindberg gjorde guld - med en cigarr', Svenska Morgenbladet, 28 May, 1912

52 Wetterhoff-Asp, 'När Strindberg gjorde guld', Julkalas, 1928

53 J.M. Mortensen, 'Strindberg guldmakare och spiritist', Stockholms Tidningen, 4 Jan., 1931; Strindberg som jag minnes honom, C.E. Fritzes Bokförlags Aktiebolag, Stockholm, 1931, 18-27

54 F. Strindberg, 'August Strindberg als Goldmacher. Der Dichter im Laboratorium', Neue Freie Presse, Wien, Feb. 1, 8, 15, 1931

55 'Möte mellan två genier: När The Svedberg analyserade Strindbergs kemiska experiment', Svenska Dagbladet, 3l Oct., 1948, 3

56 Ref. 10(a), 31

57 Ref. 23, 85

58 Ref. 5

59 G. Brandell, letter to George B. Kauffman, 1 Oct., 1980 